\title{
PENGELOLAAN ALOKASI DANA DESA KEPANJEN KECAMATAN GUMUKMAS JEMBER TAHUN ANGGARAN 2016
}

\author{
Chichi Nani Icawati \\ Universitas Muhammadiyah Jember \\ chichi@gmail.com
}

\begin{abstract}
This study focuses on the implementation of management systems carried out by the implementing teams established in each village. The implementation of accountability principle of the management of the allocation of village funds starts from the planning stage, the implementation of all activities and post activities so that the management of the allocation of village funds is expected to be accountable. This reseacrch is expected to be useful for Jember district government, especially Kepanjen village Gumukmas in an effort to improve accountability of management of fund allocation of village. This research was conducted in the village of Kepanjen Gumukmas Sub district in fiscal year 2016. Data collection methods used in this research are literature study and field study. Then the results of the study are analyzed through descriptive analysis method where this method which aims to collect, arrage, present and analyze the data so that can be obtained a clear picture of the object in the perusal. The data used in this study are primary data and secondary data with research subjects consisting of village government Kepanjen Gumukmas district. Based on the results of research, stage, planning can be seen from the meeting held by the executive team of the allocation of village funds is still less effective, where in the community participation meeting activities are still very low, due to lack of transparency of information submitted to the village community Kepanjen.
\end{abstract}

Keywords: Accountability, Allocation of village funds, Participation, Tansparency

\section{PENDAHULUAN}

Dalam undang-undang Nomor 23

Tahun 2014 tentang pemerintah daerah telah di atur mengenai pelaksanaan sistem desentralisasi di negara Indonesia, dimana pemerintah pusat memberikan kewenangan yang lebih besar kepada daerah untuk melakukan serangkaian proses, mekanisme dan tahapan perencanaaan yang dapat menjamin keselarasan pembangunan (Thomas : 2013).
Muin (2014) menyatakan bahwa krisis multidimensional yang tengah melanda bangsa Indonesia telah menyadarkan kepada kita semua akan pentingnya menggagas kembali konsep otonomi daerah. Gagasan penataan kembali sistem otonomi daerah bertolak dari pemikiran untuk menjamin terjadinya efisiensi, efektivitas, transparansi, akuntabilitas, dan demokratisasi nilai-nilai kerakyatan 
dalam praktik penyelenggaraan

Pemerintahan Daerah, memberikan deferensi bahwa otonomi daerah adalah hak, wewenang, dan kewajiban daerah otonom untuk mengatur dan mengurus sendiri urusan pemerintahan dan kepentingan setempat sesuai dengan peraturan perundang-undangan. Hal tersebut melandasi dirumuskannya Undang-Undang Nomor 6 Tahun 2014 tentang Desa. Desa merupakan ujung tombak suksesnya otonomi daerah karena didalam sistem pemerintahan desa terdapat suatu hak dan kewajiban desa untuk menjalankan roda pemerintahan supaya menimbulkan suatu kesejahteraan untuk masyarakatnya.

Alokasi Dana Desa (ADD) adalah dana yang diberikan kepada desa yang berasal dari dana perimbangan keuangan pemerintah pusat dan daerah yang diterima oleh Kabupaten/ Kota. Pemberian Alokasi Dana Desa (ADD) merupakan wujud dari pemenuhan hak desa untuk menyelenggarakan otonominya agar tumbuh dan berkembang mengikuti pertumbuhan dari desa itu sendiri berdasarkan keanekaragaman, partisipasi, otonomi asli, demokratisasi, pemberdayaan masyarakat dan meningkatkan peran pemerintah desa dalam memberikan pelayanan dan meningkatkan kesejahteraan masyarakat serta memacu percepatan pembangunan dan pertumbuhan wilayah- wilayah strategis. Alokasi Dana Desa sangat penting guna pembiayaan pengembangan wilayah tertinggal dalam suatu sistem wilayah pengembangan. Pelaksanaan Alokasi Dana Desa ini ditujukan untuk programprogram fisik dan non fisik yang berhubungan dengan indikator perkembangan desa, meliputi tingkat pendidikan, tingkat pendapatan masyarakat, dan tingkat kesehatan (Nafidah : 2015).

Konsep Alokasi dana Desa (ADD) sebenarnya bermula dari sebuah kritik dan refleksi terhadap model bantuan desa yang diberikan oleh pemerintah pusat bersamaan dengan agenda pembangunan desa sejak tahun 1969. Dalam mendesain transfer keuangan pusat dengan daerah, orde baru ternyata masih melanjutkan pola yang dipakai orde lama (Mahfudz, 2009).

Landasan Dasar Alokasi Dana Desa (ADD) yaitu Undang-Undang Nomor 6 Tahun 2014 tentang desa, Peraturan Pemerintah Nomor 47 Tahun 2015 tentang Perubahan Atas Peraturan 
Pemerintah Nomor 43 tahun 2014 tentang Peraturan Pelaksanaan Undang - Undang Nomor 6 Tahun 2014 tentang Desa, serta Peraturan Menteri Dalam Negeri Nomor 37 Tahun 2007 yang di perbaruhi dalam Nomor 113 Tahun 2014 tentang Pengelolaan Keuangan Desa.

Kabupaten Jember merupakan salah satu daerah otonomi yang ada di Jawa Timur yang telah melaksanakan prinsip-prinsip otonomi daerah dengan berusaha mengoptimalkan potensi desa demi terselenggaranya pemerintahan yang bersih. Wujud nyata Kabupaten Jember dalam membantu dan meningkatkan partisipasi pemerintah desa adalah berupaya meningkatkan alokasi dana yang dapat dipergunakan untuk mendukung penyelenggaraan dan kewenangan untuk mengurus rumah tangganya (Wikipedia, 2017).

Penduduk Kabupaten Jember yang bertempat tinggal di desa dengan berbagai permasalahannya, memberikan inisiatif dan inovasi bagi pemerintah Kabupaten Jember untuk mengembangkannya ke arah yang lebih baik. Hal ini salah satunya didorong oleh faktor ketertinggalan desa dalam kaitanya dengan kualitas sumber daya manusia dan prasarana infrastruktur desa yang masih sangat terbatas dan tidak terlepas pula dari keterbatasan dana pembangunan yang dialokasikan kepada desa.

Pemberian Alokasi Dana Desa (ADD) dari pemerintah Kabupaten Jember kepada desa pada tahun 2016 secara yuridis pengaturannya ditetapkan dalam Peraturan Bupati Jember Nomor 5 Tahun 2016 tentang Pedoman Pengelolaan Alokasi Dana Desa (ADD) di Kabupaten Jember Tahun 2016.

Alokasi Dana Desa (ADD) yang merupakan dana bantuan pemerintah Kabupaten kepada desa dipergunakan untuk menunjang peningkatan penyelenggaraan pemerintah desa dan pemberdayaan masyarakat desa. Gumukmas adalah salah satu kecamatan teletak di Kabupaten Jember yang mendapatkan dana ADD untuk dibagi kepada delapan desa. Di tahun 2016 di Kecamatan Gumukmas, desa yang mendapatkan dana ADD yang tertinggi adalah Desa Gumukmas sebesar Rp. 846.275.588, sedangkan dana ADD terendah di terima di desa Bagorejo yaitu sebesar Rp. 796.995.395.

Pelaksanaan program ADD harus menerapkan prinsip-prinsip partisipatif, responsive dan transparan. Penerapan prinsip akuntabilitas pada tahap 
pelaksanaan bukan hanya sebatas pertanggungjawaban fisik tetapi juga harus disertakan pertanggungjawaban secara administrasi yang sesuai dengan ketentuan yang telah ditetapkan oleh pemerintah (Arifiyanto, 2014)

Berdasarkan Peraturan Bupati Jember Nomor 5 Tahun 2016 tentang Pedoman Pengelolaan Alokasi Dana Desa, disebutkan bahwa diberikannya Alokasi Dana Desa (ADD) yaitu untuk membiayai program pemerintah desa dalam melaksanakan kegiatan penyelenggaraan Pemerintahan dan pelaksanaan pembangunan serta pemberdayaan masyarakat dengan meggunakan prinsip akuntabilitas yang sesuai dengan Sistem Akuntansi Pemerintah (SAP). Oleh karenanya, pendapatan jumlah alokasi dana desa di Desa Kepanjen yang senilai Rp. 816.100.093 diharapkan dapat dipertanggungjawabkan dan sesuai dengan kebutuhan merupakan salah satu bentuk desentralisasi guna mendorong good governance.

Berdasarkan latar belakang tersebut maka peneliti tertarik untuk melakukan penelitian tentang alokasi dana desa di Desa Kepanjen Kecamatan Gumukmas Jember.

\section{LANDASAN TEORI}

\subsection{Alokasi Dana Desa}

Nafidah dan Suryaningtyas (2015 : 214) menyatakan bahwa Alokasi Dana Desa (ADD) adalah bagian keuangan desa yang diperoleh dari bagi hasil pajak daerah dan bagian dari dana perimbangan keuangan Pusat dan Daerah yang diterima oleh kabupaten. Menurut Peraturan Menteri Dalam Negeri Nomor 113 Tahun 2014 tentang Pedoman Pengelolaan Keuangan Desa, Alokasi Dana Desa, selanjutnya disingkat ADD adalah dana perimbangan yang diterima kabupaten/kota dalam Anggaran Pendapatan dan Belanja Daerah kabupaten/kota setelah dikurangi Dana Alokasi Khusus.

\subsection{Peraturan Bupati Jember Nomor 5 Tahun 2016}

Berdasarkan Peraturan Bupati Jember Nomor 5 Tahun 2016 tentang Pedoman Pengelolaan Alokasi Dana Desa menyatakan bahwa Alokasi Dana Desa (ADD) didistribusikan secara proposional untuk masing-masing desa. Variabel perhitungan Alokasi Dana Desa (ADD) secara proposional antara lain adalah jumlah kepala desa dan perangkat desa jumlah BPD serta 
jumlah RT/RW, jumlah penduduk, luas wilayah, angka kemiskinan dan indek kesulitan geografis. Berdasarkan dari uraian tersebut bobot variabel dapat ditentukan sebagai berikut: JKP sebesar 50\% (lima puluh persen), JP sebesar 15\% (lima belas persen), LW sebesar $10 \%$ (sepuluh persen), AK sebesar 15\% (lima belas pesen) dan IKG sebesar $10 \%$ (sepuluh persen) dapat dihitung dengan cara: ADD suatu Desa = Sumber anggaran ADD Kabupaten $\mathrm{x}$ $(50 \% \times \mathrm{JKP})+(15 \% \times \mathrm{JP})+(10 \% \times$ $\mathrm{LW})+(15 \% \mathrm{x} A K)+(10 \% \mathrm{x} \mathrm{IKG}))$.

Nilai variabel dapat diuraikan sebagai berikut:

1. JKP merupakan jumlah Kepala Desa dan Perangkat Desa, jumlah BPD serta jumlah RT/RW suatu Desa terhadap keseluruhan jumlah Kepala Desa dan Perangkat Desa, jumlah BPD serta jumlah RT/RW Desa seKabupaten Jember

2. JP merupakan hasil pembagian jumlah penduduk suatu Desa terhadap keseluruhan jumlah penduduk se-Kabupaten Jember

3. LW merupakan hasil pembagian luas wilayah suatu desa terhadap luas wilayah Kabupaten Jember

4. AK merupakan hasil pembagian jumlah penduduk miskin suatu Desa terhadap keseluruhan jumlah penduduk miskin se-Kabupaten Jember;

5. IKG merupakan hasil pembagian nilai IKG suatu Desa terhadap keseluruhan jumlah IGK seKabupaten Jember.

Alokasi Dana Desa (ADD) yang digunakan untuk membiayai bidang prioritas Penyelenggaraan Pemerintahan Desa diperhitungkan terlebih dahulu untuk mencukupi kebutuhan :

1. Penghasilan Tetap (PT) Kepala Desa dan Perangkat Desa :

2. Tunjangan BPD

3. Insentif RT/RW

4. Operasional Linmas

5. Operasional Desa Online

6. Alokasi Dana Desa yang digunakan untuk membiayai bidang prioritas Pemberdayaan Masyarakat sebagaimana dimaksud pasal 7 ayat (2) diperhitungkan terlebih dahulu untuk mencukupi kebutuhan :

a. Operasional TP PKK Desa

b. Operasional Lembaga Pemberdayaan Masyarakat Desa (LPMD) dan Karang Taruna

c. Operasional Kelompok Lanjut Usia (Karang Wreda)

d. Pelatihan pengelolaan kekayaan dan keuangan Desa 


\section{METODE PENELITIAN}

Metode penelitian yang dilakukan menggunakan metode penelitian kualitatif, dimana pengumpulan data dilakukan dengan cara observasi, wawancara, dan dokumentasi. Untuk memperoleh data dan informasi yang akurat, peneliti akan melakukan wawancara kepada informan-informan di Desa Kepanjen Kecamatan Gumukmas Kabupaten Jember. Informan yang dipilih merupakan orang-orang yang terlibat langsung dan memahami serta dapat memberikan informasi tentang Pengelolaan ADD, yaitu pemerintah desa selaku tim pelaksana desa dan lembaga pemberdayaan masyarakat desa selaku tim pelaksana kegiatan. Informan dari pemerintah desa diwakili oleh Kepala Desa, Sekertaris Desa dan Bendahara Desa Kepanjen. Sedangkan dari pihak Lembaga Pemberdayaan Masyarakat (LPM) Desa Kepanjen diwakili oleh Ketua dan Anggota yang berkompeten dalam pengelolaan ADD.

\section{HASIL DAN PEMBAHASAN}

\subsection{Gambaran Umum Obyek Penelitian}

Desa Kepanjen dikenal sebagai desa agraris, memiliki potensi alam yang cukup prospektif bagi pengembangan perekonomian wilayah ditingkat desa. Sesuai dengan potensi ekonomi desa yang ada, perekonomian di Desa Kepanjen masih mengandalkan pada sektor pertanian sebagai basis dan penggerak roda perekonomian wilayah. Pertanian sebagai sektor unggulan sampai saat ini masih memiliki peran yang dominan dan strategis bagi pembangunan perekonomian baik sebagai : penyedia bahan pangan, bahan baku olahan, peningkatan pendapatan desa dan masyarakat serta penyerapan tenaga kerja dalam jumlah yang signifikan. Sumberdaya yang ada saat ini yang menjadi potensi ekonomi yang unggul adalah dibidang pertanian dengan beberapa produk yang dihasilkan meliputi : padi, jagung, cabe kecil, kacang tanah, semangka, dan tanaman palawija lainnya.

Berdasarkan hasil sensus penduduk, jumlah penduduk pada Tahun 2016 sebanyak 10.559 jiwa yang terdiri dari 5.175 (49\%) laki-laki dan 5.384 (51\%) perempuan. Hal ini menjadi pertimbangan penting karena penduduk merupakan sumberdaya pembangunan, sekaligus sebagai subyek dan sasaran dari pelaksanaan pembangunan. 


\subsection{Akuntabilitas Pengelolaan}

Alokasi Dana Desa Kepanjen

\subsubsection{Perencanaan ADD}

Mekanisme perencanaan ADD di

Desa Kepanjen Kecamatan Gumukmas secara kronologis dapat dijabarkan sebagai berikut:

1. Kepala desa sebagai penanggungjawab ADD mengadakan musyawarah desa guna membahas rencana penggunaan $\mathrm{ADD}$

2. Musyawarah desa dihadiri oleh unsur pemerintah desa, Badan Musyawarah Desa (BPD). Lembaga Pemberdayaan Masyarakat Desa (LPMD), dan juga tokoh masyarakat serta wajib dihadiri oleh Tim Fasilitator Kecamatan

3. Tim Pelaksana Desa menyampaikan rancangan penggunaan ADD secara keseluruhan kepada peserta musyawarah desa. Rancangan penggunaan ADD didasarkan pada skala prioritas hasil musrenbangdes tahun sebelumnya.

4. Rancangan penggunaan ADD yang telah disepakati dalam musyawarah desa, dituangkan dalam rencana penggunaan ADD yang merupakan salah satu bahan penyusun APBDes.
Apabila ditinjau dari partisipasi dalam hal pengambilan keputusan perencanaan penggunaan dana ADD dapat dikatakan bawa tingkat partisipasi masyarakat sudah cukup sesuai dengan Permendagri Nomor 113 tahun 2014 Tentang Pengelolaan Keuangan. Hal ini dibuktikan dengan tingkat kehadiran masyarakat dan musyawarah desa Kepanjen yang mencapai angka 53\%, Namun angka tersebut masih kurang maksimal. Karena masih cukup banyak unsur desa yang tidak menghadiri forum tersebut dan masih sedikit yang menyampaikan aspirasi/pendapat terkait dengan kegiatan yang akan dilakukan seperti, menyusun agenda dan prioritas pelayanan, serta mengembangkan program-program pelayanan yang sesuai dengan kebutuhan dan aspirasi masyarakat.

Penganggaran merupakan bagian dari proses perencanaan yang terdiri dari penyusunan APBDes desa dan penyusunan RKP desa. Berdasarkan hasil penelitian, diketahui ADD yang diterima di Desa Kepanjen adalah sebesar Rp. 816.100.093, dimana pengalokasian anggaran ADD oleh pemerintah Desa Kepanjen berpedoman pada Perbup Nomor 5 Tahun 2016, yaitu digunakan untuk penyelenggaraan 
operasional pemerintah desa sebesar Rp. 428.500.000 atau sekitar 52\%, Kegiatan Pemberdayaan masyarakat sebesar Rp 36.000.000 atau sekitar $4,41 \%$, pembinaan kemasyarakaan sebesar Rp. 13.200.000 atau sebesar $1,617 \%$, dan pengeluaran tidak terduga sebesar Rp. 8.600.000 atau sebesar $1,016 \%$.

Hasil perencanaan yang dicapai di Desa Kepanjen Kecamatan Gumukmas sudah sesuai dengan Peraturan Bupati Jember Nomor 5 Tahun 2016 tentang Pedoman Pengelolaan alokasi Dana Desa yang tercantum pada bagian kelima pasal 8 dan 9 tentang penggunaan Alokasi Dana Desa.

Dari sisi transparasi perencanaan, seluruh perangkat Desa Kepanjen diwajibkan memberi informasi kepada masyarakatnya mengenai kegiatan apa yang akan dilaksanakan di lingkungannya, dimana dana itu berasal dari dana ADD. Selain itu juga perangkat desa harus bersikap terbuka oleh adanya kritik yang akan diberikan oleh masyarakat. Namun berdasarkan observasi peneliti, pemerintah Desa Kepanjen belum melaksanakan transparasi yang cukup atau kurang terbuka terhadap seluruh lapisan masyarakat, sehingga tidak seluruh masyarakat mengetahui mengenai kegiatan apa yang akan dilaksanakan dilingkungannya. Hal ini ditunjukan dengan tidak adanya papan informasi dan penulisan anggaran terkait pembangunan di Desa Kepanjen.

\subsubsection{Pelaksanaan ADD}

Pelaksanaan kegiatan-kegiatan yang dananya bersumber dari dana ADD sepenuhnya dilaksanakan oleh Tim Pelaksanaan Desa (TPD). Guna mendukung keterbukaan dan penyampaian informasi secara jelas kepada masyarakat, maka disetiap kegiatan fisik harus dipasang papan informasi tentang kegiatan-kegiatan di lokasi tersebut. Namun di Desa kepanjen pada tahun 2016 hal tersebut tidak dilakukan sehingga pemerintah Desa Kepanjen masih belum melaksanakan proses transparasi dengan baik terhadap seluruh lapisan masyarakat.

Dari sisi prinsip akuntabilitas, pelaksanaan ADD ditempuh melalui sistem pelaporan yaitu laporan bulanan dan laporan masing-masing tahapan kegiatan. Seperti yang dijelaskan oleh Sekertaris Desa Kepanjen sebagai berikut:

“ kami selalu membuat laporan disetiap kegiatan, baik awal tahun 
maupun akhir tahun. Karena melalui laporan tersebut kami bisa mengevaluasi serta melalui laporan tersebut juga merupakan syarat untuk pengajuan anggaran di tahun berikutnya."

Dari hasil wawancara tersebut menunjukan bahwa didalam pelaksanaan ADD senantiasa dilaporkan perkembangan pelaksanaan kegiatan oleh pengelola ADD di tingkat desa. Terutama tentang kegiatan fisik dan penyerapan dana, dengan demikian dapat diketahui bahwa pertanggungjawaban pengelola ADD di tingkat Desa sudah memenuhi ketentuan pembuatan laporan kegiatan ADD yang bertahap dan laporan akhir kegiatan sesuai dengan Peraturan Bupati Jember Nomor 5 Tahun 2016 tentang Pedoman Pengelolaan alokasi Dana Desa yang tertera dalam pasal 27, 28 dan 29.

\subsubsection{Penatausahaan ADD}

Penatausahaan merupakan rangkaian kegiatan yang dilakukan secara sistematis (teratur dan masuk akal/logis) dalam bidang keuangan berdasarkan prinsip, standar, serta prosedur tertentu sehingga informasi aktual (informasi yang sesungguhnya) berkenaan dengan keuangan dapat segera diperoleh. Tahap ini merupakan proses pencatatan seluruh transaksi keuangan yang terjadi dalam satu tahun anggaran. Lebih lanjut, kegiatan penatausahaan keuangan mempunyai fungsi pengendalian terhadap pelaksanaan APBDesa. Hasil dari penatausahaan adalah laporan yang dapat digunakan untuk pertanggungjawaban pengelolaan keuangan itu sendiri.

Berikut adalah pernyataan dari Bendahara Desa Kepanjen:

"setiap terjadi transaksi penerimaan maupun pengeluaran harus disertai dengan bukti transaksi baik berupa nota maupun kwitansi. Bukti transaksi di masukkan didalam buku kas desa, karena nantinya akan digunakan sebagai pertannggungjawaban pengelolaan Keuangan desa”.

Dari pernyataan oleh Bendahara Desa diatas, maka dapat disimpulkan bahwa dalam proses penatausahaan di Desa Kepanjen sudah sesuai dengan peraturan yang berlaku, dalam administrasi keuangan juga tidak ada kendala dan bukti transaksi selalu disertakan dengan lengkap. Karena Dalam laporan pertanggungjawaban keuangan desa harus disertakan dengan bukti pengeluaran dana seperti nota maupun kwitansi. Hal tersebut harus dipenuhi oleh aparat pemerintah desa. 


\subsubsection{Pelaporan}

dan

\section{Pertanggungjawaban ADD}

Pelaporan adalah kegiatan yang dilakukan untuk menyampaikan hal-hal yang berhubungan dengan hasil pekerjaan yang telah dilakukan selama satu periode tertentu sebagai bentuk pelaksanaan tanggungjawab (pertanggungjawaban) atas tugas dan wewenang yang diberikan. Laporan merupakan suatu bentuk penyajian data dan informasi mengenai sesuatu kegiatan ataupun keadaan yang berkenaan dengan adanya suatu tanggung jawab yang ditugaskan. Pada tahap ini, Pemerintah Desa menyusun laporan realisasi pelaksanaan APBDes paling lambat per 31 Desember tahun yang berkenaan disampaikan kepada Bupati/walikota.

Pelaporan dilakukan untuk mengetahui proses pengelolaan keuangan desa seperti: perkembangan kegiatan, penyerapan dana yang digunakan, permasalahan yang terjadi dan cara pemecahannya beserta hasil pencapaianya.

Dari pernyataan diatas berikut hasil wawancara penulis dengan Bendahara Desa:

"setiap pengeluaran keuangan harus disertai dengan bukti-bukti seperti nota maupun kwitansi yang nantinya akan digunakan sebagai bahan pelaporan bulanan. Barangbarang yang dibeli juga harus jelas kegunaanya. Dan mengenai sistem pelaporanya dilaksanakan secara berjenjang dari TPK desa ke Kecamatan, dari pihak Kecamatan kemudian melaporkanya ke pihak Kabupaten dengan format pelaporan sesuai dengan yang telah ditentukan, pelaporan ini dilaksanakan setiap bulan dan setiap akhir pelaksanaan kegiatan",

Dari hasil wawancara tersebut dapat disampaikan bahwa Desa Kepanjen sudah melaksanakan pelaporan pertanggungjawaban dengan baik. Pemerintah desa melakukan laporan secara periodik sesuai dengan peraturan yang berlaku.

Adapun pertanggungjawaban ADD di Desa Kepanjen terintegrasi dengan pertanggungjawaban APBDes. Hal ini sesuai dengan Peraturan Bupati Jember Nomor 5 Tahun 2016 Tentang Pedoman Pengelolaan Alokasi Dana Desa. Peraturan daerah tersebut dimaksudkan untuk memberikan landasan hukum pada bidang keuangan desa, sumber keuangan desa, pengelolaan keuangan desa, dan anggaran pendapatan serta belanja desa.

Penguatan keuangan desa dilakukan untuk menguatkan pilar transparansi dan akuntabilitas pengelolaan keuangan desa harus 
dilaksanakan secara efektif dan efisien, transparan dan akutabel. ADD yang merupakan salah satu sumber utama pendapatan desa juga harus dipertanggungjawabkan secara transparan kepada masyarakat maupun kepada pemerintah kabupaten sebagai institusi pemberi kewenangan

Evaluasi pelaksanaan program ADD telah membimbing masyarakat untuk berpartisipasi didalam memberikan masukan dan koreksi di dalam pelaksanaan ADD. Selain pemerintah memiliki peran yang penting dalam terlaksananya dan kesuksesan kegiatan, masyarakat juga memiliki peran yang sama dalam hal evaluasi.

Pengelolaan ADD di Desa Kepanjen juga telah melaksanakan pertanggungjawaban administrasi keuangan ADD dengan baik yaitu setiap pembelanjaan yang bersumber dari ADD harus disertai dengan bukti seperti nota pembelian. Selama dalam pelaksanaan ADD tetap dituntut untuk pertanggungjawabanya di setiap pembelanjaan. Apabila hal tersebut dilakukan secara terus menerus maka akan tercipta bentuk laporan yang akuntabel sesuai dengan ketentuan yang ada.
Adapun pertanggungjawaban ADD dari segi fisik maupun non fisik dapat dikatakan baik, Hal ini didukung penerapan dilapangan yang menunjukan bahwa semua yang telah dikeluarkan sudah dipertanggungjawabkan secara fisik dan juga secara administrasi keuangan. Adapun pertanggungjawaban ADD dari sisi fisik di Desa Kepanjen dapat dikatakan berhasil dengan baik dan sudah selesai $100 \%$.

Hasil-hasil pembangunan yang bersumber dari dana ADD di Desa Kepanjen dapat dilihat pada Tabel 1 sebagai berikut:

Tabel 1 Hasil Pembangunan yang Bersumber Dari Dana ADD Di Desa Kepanjen Tahun 2016

\begin{tabular}{|c|l|c|c|c|}
\hline No & $\begin{array}{l}\text { Sarana yang } \\
\text { Dibangun }\end{array}$ & $\begin{array}{c}\text { Besarnya } \\
\text { (Rp.) }\end{array}$ & Persen & Hasil \\
\hline 1. & Nilai ADD & 816.100 .093 & & \\
\hline 2. & $\begin{array}{l}\text { Pembangunan } \\
\text { Jalan Dusun } \\
\text { Panggulmlati }\end{array}$ & $180.441 .993,75$ & $22,11 \%$ & Baik \\
\hline 3. & $\begin{array}{l}\text { Pembangunan } \\
\text { Jalan Dusun } \\
\text { Panggulmlati }\end{array}$ & $93.435 .841,59$ & $11.44 \%$ & Baik \\
\hline 4. & $\begin{array}{l}\text { Pembangunan } \\
\text { Jalan Dusun } \\
\text { Panggulmlati }\end{array}$ & $56.224 .839,12$ & $6,88 \%$ & Baik \\
\hline & Jumlah & $330.102 .674,46$ & $40,43 \%$ & Baik \\
\hline
\end{tabular}

Sumber Data: Desa Kepanjen, 2016 (data diolah)

Tabel 1 menunjukan bahwa jumlah ADD yang diterima oleh Desa Kepanjen Kecamatan Gumukmas adalah sebesar Rp. 816.100.093, dimana 
pengalokasian anggaran Alokasi Dana

Desa oleh pemerintah Desa Kepanjen diperuntukkan untuk pembangunan desa dengan jenis kegiatan yakni, pembangunan Jalan Dusun Panggulmlati dengan anggaran sebesar Rp. 180.441.993,75 atau sekitar 22,11\%, pembangunan Jalan Dusun Panggulmlati dengan anggaran sebesar Rp. 93.435.841,59 atau sebesar 11,44\%, pembangunan Jalan Dusun Panggulmlati dengan anggaran sebesar Rp. 56.224.839,12 atau sebesar 6,88\%. Dari data tersebut menunjukan bahwa hasil pembangunan yang dicapai di Desa Kepanjen Kecamatan Gumukmas rata-rata dapat terealisasi dengan baik dan dapat dipertanggungjawabkan.

Dengan dilakukannya prinsip akuntabilitas secara bertahap akhirnya akan mendukung kepercayaan masyarakat terhadap pelaksanaan pembangunan desa yang pada akhirnya akan tercapai tingkat partisipasi masyarakat desa yang secara komulatif akan mendukung keberhasilan pembangunan daerah. Untuk mendukung hal tersebut, pemerintah desa juga harus merespon kritik dan dan saran dari masyarakat dalam forum musyawarah desa.

\subsubsection{Pembinaan dan Pengawasan Pembangunan Desa \\ Proses pembinaan dan} pengawasan di Desa Kepanjen dilakukan oleh Camat atas nama Bupati, pengawasan fungsional diakukan oleh Inspektorat Kabupaten, BPKP dan BPK, serta BPD (Badan Permusyawaratan Desa) dalam bentuk rekomendasi umpan balik dari laporan pertanggungjawaban ADD yang telah di serahkan. Hal ini telah sesuai dengan Peraturan Bupati Jember Nomor 5 Tahun 2016 tentang Pedoman Pengelolaan Alokasi Dana Desa.

Disamping itu, juga diperlukan keikutsertaan Masyarakat Desa dalam mengawasi perencanaan dan pelaksanaan pembangunan desa. Namun berdasarkan observasi peneliti, pengawasan dari masayarakat belum berjalan maksimal dikarenakan kurangnya transparansi dan informasi dari pemerintah Desa Kepanjen mengenai pembangunan desa, yang ditunjukan dengan tidak adanya papan informasi untuk pencatatan perencanaan dan pelaksanaan pembangunan Desa. 


\section{KESIMPULAN DAN SARAN}

\subsection{Kesimpulan}

Berdasarkan hasil analisis mengenai akuntabilitas pengelolaan Alokasi Dana Desa (ADD) di Desa Kepanjen Kecamatan Gumukmas Kabupaten Jember Tahun 2016 maka dapat di ambil beberapa kesimpulan sebagai berikut:

1. Perencanaan ADD di Desa Kepanjen pada Tahun 2016, mulai dari musyawarah desa sampai dengan proses pengajuan RABDes sudah cukup baik dan sesuai dengan Peraturan Bupati Jember Nomor 5 Tahun 2016 tentang Pedoman Pengelolaan alokasi Dana Desa. Namun dalam hal tingkat partisipatif masyarakat masih kurang maksimal, yang ditunjukkan dengan tingkat kehadiran masyarakat dan unsur desa dalam musyawarah Desa Kepanjen yang hanya mencapai angka 53\%.

2. Pelaksanaan ADD di Desa Kepanjen sudah dilaksanakan sesuai Peraturan Bupati Nomor 5 Tahun 2016. Hal ini ditunjukkan dengan adanya laporan disetiap kegiatan, baik pada awal tahun maupun akhir tahun.
3. Penatausahaan ADD di Desa Kepanjen pada tahun 2016 sudah sesuai dengan peraturan Peraturan Bupati Nomor 5 Tahun 2016, dimana pemerintah Desa Kepanjen telah menyusun laporan secara periodik dan di dukung juga dengan bukti-bukti transaksi.

4. Pelaporan dan pertanggungjawaban ADD di Desa Kepanjen sudah dilaksanakan sesuai dengan Peraturan Peraturan Bupati Nomor 5 Tahun 2016. Hal ini ditunjukkan dengan hasil observasi dilapangan, dimana semua yang dilaksanakan sudah dipertanggungjawabkan secara fisik dan juga secara administrasi keuangan. Adapun pertanggungjawaban ADD dari segi pembangunan fisik di Desa Kepanjen juga telah diselesaikan dengan baik.

5. Pembinaan dan Pengawasan pembangunan di Desa Kepanjen pada tahun 2016 sudah dilakukan cukup baik, dimana pengawasan dilakukan oleh Camat atas nama Bupati, pengawasan fungsional diakukan oleh Inspektorat Kabupaten, BPKP dan BPK, serta BPD (Badan Permusyawaratan Desa) dalam bentuk rekomendasi 
umpan balik dari laporan pertanggungjawaban ADD yang telah di serahkan. Namun tingkat partisipatif masyarakat dalam hal pengawasan masih sangat kurang, dikarenakan kurangnya informasi yang disediakan oleh Pemerintah Desa Kepanjen dalam bentuk papan informasi terkait pelaksanaan pembangunan desa.

\subsection{Saran}

Beberapa saran yang diberikan peneliti adalah sebagai berikut:

1. Pemerintah Desa Kepanjen perlu meningkatkan akuntabilitas dalam pengelolaan Alokasi Dana Desa (ADD) dengan selalu mengikuti peraturan perundang-undangan yang terbaru, agar pemerintah desa dapat menjalankan tugas dan tanggungjawabnya dengan baik untuk kesejahteraan masyarakat desa.

2. Pemerintah Desa Kepanjen di harapkan lebih transparan lagi terhadap pengelolaan dana ADD, seperti memasang papan informasi mengenai anggaran pengeluaran dan pemasukan pembangunan desa di setiap kegiatan yang dilaksanakan.

\section{DAFTAR PUSTAKA}

Dwi Febri Arifiyanto dan Taufik Kurrohman. 2014. Akuntabilitas Pengelolaan Alokasi Dana Desa Di Kabupaten Jember. Jurnal: Jurnal Riset Akuntansi Keuangan. Vol 2. No. 3. 2014

Fasli Jalal dan Dedi Supriadi. 2001. Reformasi Pendidikan Dalam Konteks Otonomi Daerah. Yogyakarta: Adicipta

Fattah. 2009. Landasan Manajemen Sumber Daya Manusia. Yogyakarta: C.V Andi Offset

Hanif Nurcholis. 2011. Pertumbuhan Dan Penyelenggaraan Pemerintah Desa. Jakarta: Erlangga.

John M. Echols dan Hassan Shadily dalam Kamus Inggris Indonesia, Jakarta: PT. Gramedia, 2000

Mahfudz. 2009. Analisis Dampak Alokasi Dana Desa (Add) Terhadap Pemberdayaan Masyarakat Dan Kelembagaan Desa. Jurnal: Jurnal Organisasi dan Manajemen, Vol 5, No. 1, Hal 10-22 (2009)

Miles, Matthew B. dan A. Michael Huberman. 2009. Analisis Data Kualitatif. Jakarta: UI-Press

Moleong Lexy. 2004. Metodologi Penelitian Kualitatif. Bandung: Remaja Sosdakarya

Mardiasmo. 2005. Akuntansi Sektor Pubik Edisi Kedua. Yogyakarta: Badan Penerbit Andi

Nafidah dan suryaningtyas. 2015. Akuntabilitas Pengelolaan Alokasi Dana Desa Dalam Upaya Meningkatkan Pembangunan dan Pemberdayaan Masyarakat. Jurnal: Jurnal Bisnis dan 
Manajemen Islam, Vol 3, No.1 (2015)

P. Siagian Sondang. 2003. Kepemimpinan organisasi dan Perilaku Administrasi. Jakarta: Penerbit Gunung Agung

Patton. 1987. Qualitative Education Methods. Everly Hills: Sage Publication

Rathomi viki, dkk. 2014. Kedudukan Kepala Desa Dan Kepala Kelurahan Berdasarkan UndangUndang Nomor 32 Tahun 2004 Tentang Pemerintahan Daerah. Jember: Universitas Negeri Jember.

Rudianto. 2006. Akuntansi Manajemen Informasi untuk Pengambilan Keputusan Manajemen. Jakarta: Gramedia

Riduwan. 2004. Metode Dan Teknik Menyusun Tesis. Bandung: Alfabeta

Riyanto Teguh. 2015. Akuntabilitas Finansial Dalam Pengelolaan Alokasi Dana Desa di Kantor Desa Perangkat Selatan Kecamatan Marangkayu Kabupaten Kutai Kertanegara. Jurnal: Ejournal Administrasi Negara, Vol 3, No.1 (2015), ISSN 2337-7542.

Sekaran Uma. 2011. Reseach Methods For Bussiness Edisi 1 And 2. Jakarta: Salemba Empat.

Simbolon, Anton. 2006. Akuntabilitas Birokrasi Publik. Edisi Revisi. Yogyakarta: UGM

Sjafari Agus. 2009. Akuntabilitas Sektor Publik Sebagai Perwujutan Good Govermance. Jurnal: Jurnal Ilmiah Niagara, Vol 1, No.3 (2009)
Sonny Sumarsono. 2010. Manajemen Keuangan Pemerintahan. Yogyakarta: Graha Ilmu

Sumardi Dkk. 2010. Deskripsi Dan Identifikasi Ciri-ciri Kuantitatif Kultivar Padi Gogo Lokal. Bengkulu: Akta Agrosia [Online]

Sugiyono. 2008. Metode Penelitian Kuantitatif Kualitatif dan $R \& D$. Bandung: Alfabeta.

Supriyono Agus. 2009. Cooperative Learning. Yogyakarta: Pustaka Pelajar

Sugiyono. 2013. Statistika Untuk Penelitian. Bandung: Alfabeta

Sankri. 2005. Pemantapan Kompetensi Sumberdaya Aparatur Daerah.

Thomas. 2013. Pengelolaan Alokasi Dana Desa Di Desa Sebawang Kecamatan Sesayap Kabupaten Tana Tidung. Jurnal: Ejournal Pemerintahan Integratif, Vol 1, No.1, Hal 51-64 (2013).

Widjaja Amin. 2009. Akuntansi Manajemen. Jakarta: Harvindo 